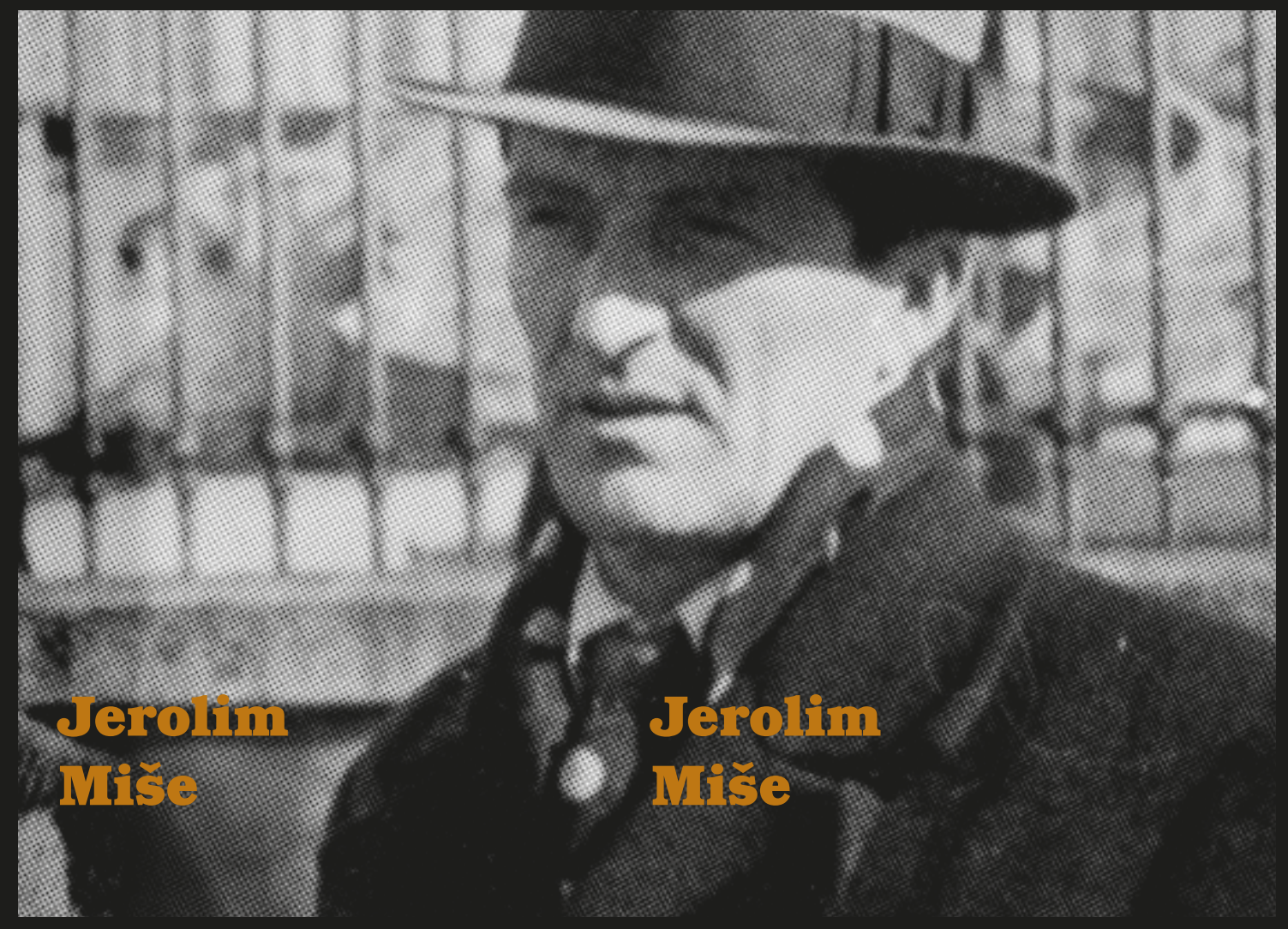

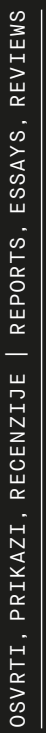




\section{S ONU STRANU}

\section{SLIKARSTVA}

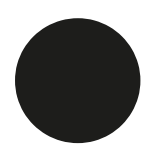

Jirsak, Libuše, ur., Šeparović, Ana, prir.

Jerolim Miše: dokumenti, vrijeme, kritike, Zagreb: Moderna galerija, 2020.

DOI: 10.31664/zu.2021.108.09

U biblioteci Povijest Moderne galerije naša je središnja čuvarica modernoga likovnog izraza uoči preimenovanja (od 2021. Nacionalni muzej moderne umjetnosti) objavila petu u nizu monografija, ovoga puta o slikaru, likovnom kritičaru i esejistu Jerolimu Miši. Osim svojevrsna uvodnika urednice dr. sc. Libuše Jirsak o odnosu Miše i Moderne galerije, u kojem prikazuje niz važnih i zanimljivih činjenica o umjetničkim, ali i političkim odnosima povezanima s radom Galerije i slikarovim angažmanom, te izbora bibliografije njegovih tekstova i onih o njemu - monografiju fundira analiza povjesničarke umjetnosti, znanstvene suradnice i leksikografkinje dr. sc. Ane Šeparović, koja je na Mišinu stvaralaštvu i doktorirala, o njemu objavila autorsku monografiju, postavila izložbu (Jerolim Miše: od buntovnika do barda, Moderna galerija, Zagreb, 2020; Split, 2021.) te objavila niz važnih znanstvenih studija, čiji se prinos očituje i u tome što ne slijedi samo uobičajenu i dugo dominirajuću formalističku analizu likovnoga stvaralaštva, usmjerenu na estetiku predmeta (umjetničkoga djela) unutar kojega se slikara hvali ako vjerno poštuje i svladava uzuse tehnike, nego nastoji kritički sagledati te u tadašnji i suvremeni društveno-politički i ideologijski kontekst smjestiti ne samo njegovo likovno nego i kritičarsko-likovno te esejističko stvaralaštvo kojima razotkriva metonimiju skrivenu u pozadini samoga slikarstva, u raskrivenosti slike te u njezinu ogoljenju i svojevrsnom kontekstualnom raščarenju.
Sl. I Naslovnica, Jerolim Miše: dokumenti, vrijeme, kritike, Zagreb: Moderna galerija, 2020 .

\section{Goran Sunajko}

Odsjek za filozofiju, Filozofski fakultet Sveučilišta u Zagrebu 
Da je tomu tako, odnosno da autorica nastavlja s istom smjelošću kritičkoga sagledavanja stvaralaštva jednoga neupitnog barda, potvrđuje krajnje nedvosmislen i provokativan naslov studije Građanski elitist Jerolim Miše i njegova kritička misao. Šeparović je studiju koncipirala istodobno kronološki i tematski, uspješno detektiravši kako je tematika slikareva izraza bila uvjetovana promjenama u kronologiji događaja. Međutim, u bitnome je autoričin koncept podijeljen na istraživanje onoga što u estetičkoj (filozofijskoj) teoriji određujemo subjektivističkom (estetika akta) i objektivističkom (estetika predmeta) estetikom. Upravo je na taj način „prepolovila” slikara na fazu subjektivacije i fazu objektivacije u koje je smjestila različite teme, od mladenačkog zanesenjaštva stvaralaštvom, filozofskim idejama, genijem i nacionalnim osvještenjem te podupiranjem društvenoga i umjetničkoga djelovanja žena, do posve oprečnih određenja elitizma, likovnoga formalizma i antifeminizma.

Šeparović kreće od postavke da Mišin likovno-kritički opus određuju dvije dominantne vrijednost-građanski antimodernizam i elitizam (elitistički pristup umjetnosti) - koje se, unatoč ipak bitnim odstupanjima, mogu prepoznati u objema fazama njegova stvaralaštva. Razdoblje subjektivacije, kako je sama naziva, autorica smješta između 1911. i 1922., kada Mišinom vizijom umjetnosti dominira stvaralaštvo (estetika akta) smješteno u, aristotelovski rečeno, umjetnikovu dušu. U njoj naglašava Mišinu zaokupljenost idejom o umjetniku geniju, kojega autorica povezuje s njegovim elitizmom. U ovoj fazi utvrđuje da na slikara utječe nekoliko filozofskih strujanja aktualnih početkom 20. stoljeća. Prije svega filozofija života (Lebensphilosophie) i vitalizam, koji doista na najbolji način podržavaju subjektivističku estetiku jer stvaralaštvo nije usmjereno objektu (predmetu) kao proizvodnji nečeg stvaratelju izvanjskoga (umjetničkoga djela), nego je neodvojivo od života, odnosno postaje život sam, kako je to argumentirao Nietzsche. Autoričinim riječima, „subjekt uživljavanjem pretače svoju vlastitu životnost u umjetničko djelo" (29). ${ }^{1}$ Time vitalizam i filozofija života, zaključuje Šeparović, čine filozofski okvir slikareve misli. Mišin odlazak na studij u Rim, dade se iščitati iz autoričinih zaključaka, najmanje je dvojako utjecao na hrvatskoga slikara, a središnja figura toga utjecaja bio je Meštrović. U njem je on vidio utjelovljenje ideje genija te je preko njega dospio do ideje jugoslavenstva kao nacionalnoga određenja. Autorica ukazuje na činjenicu da se Mišin stil mijenja, jezik postaje stilski izražen te dominira ekstatičan diskurs blizak Nietzscheovu Zaratustri. Osim jezika mijenja se i fokus pa umjetnost nije samo stvaralačka samosvrha, nego zadobiva tendencioznost usmjerenu jugoslavenskoj ideji. U ovom važnom obratu Mišina razumijevanja umjetnosti autorica naglašava kako „ulogu duhovnog vođe trebao bi imati genij Ivan Meštrović koji intenzivnim duševnim proživljavanjima nacionalni duh pretače u umjetnost” (26). Pristup bi otvorio i druga pitanja da je, iako joj to nije bilo u prvom planu, autorica naglasila kako ovdje pojam genija ima nešto tradicionalniji i sasvim oprečan smisao u odnosu na Nietzscheov antinacionalan, pa i protunacionalan, modernistički prožet subjektivizmom. Iz njezine je argumentacije vidljivo da je riječ i o razumijevanju genija bliska razdoblju njemačkoga romantizma i pratećega mu njemačkoga filozofskog idealizma (osobito Fichteova i Hegelova), koji su bili usmjereni izgradnji njemačke nacionalne države sredinom 19. stoljeća, što se dade iščitati iz autoričinih riječi kako za Mišu nacionalizam predstavlja novu religiju. Valjalo bi propitati bi li se ne samo Mišina orijentacija geniju koji ima ponijeti nacionalnu kulturu do razine nacionalne države južnoslavenskih naroda mogla razumjeti i na ovaj način, za što nam osnovu pruža i autoričin zaključak da „prema Miši, Meštrović ima izražen nacionalni instinkt, ali i duševnu primordijalnost (primitivnost) pomoću kojih u stvaralačkom uzbuđenju (,grč', , kidanja', ,ekstaze', Rausch) proizvodi umjetničko djelo" (36).

U fazi subjektivacije valja izdvojiti i Mišin zagovor ženskoga društvenog angažmana, koji autorica sjajno pozicionira pokazujući ga ambivalentnim u ranoj, a posve antifeminističkim u zreloj fazi slikareva djelovanja. Pod utjecajem Društva Medulić, koje kasnije osniva Proljetni salon u cilju jačanja integralnoga jugoslavenstva, Miše
1

Brojke u zagradama odnose se na stranice citiranog djela Ane Šeparović, „Građanski elitist Jerolim Miše i njegova kritička misao”, u: Jirsak, Libuše, ur., Šeparović, Ana, prir. Jerolim Miše: dokumenti, vrijeme, kritike, Zagreb: Moderna galerija, 2020., I6-66. 
zagovara uključenje žena u okviru što šire političke baze. Šeparović nam otkriva kako se upravo u tom razdoblju zaljubljuje u buduću suprugu Anku, ali i u skladu sa svojim očitim feminističkim pristupom, naglašava kako Anku razumijeva iz „muške” perspektive te, ne propitujući patrijarhalnu paradigmu, ženi dodjeljuje ulogu stvaranja ugodnoga (toplina, obzirnost, bliskost, otmjen stil) okruženja muškarcu, a što se još bolje vidi u katalogu izložbe (Jerolim Miše-od buntovnika do barda), u kojem Šeparović na izniman način obrazlaže razliku uočenu u ženskim i muškim portretima koje dijeli svrstanost muškaraca u građanski i intelektualni ambijent (primjerice knjiga u ruci ili slika u pozadini), a žene, putem snažne sugestivnosti, u kućno, obiteljsko okruženje (uz poneku iznimku pripadnica višega društvenog sloja).

Drugu fazu slikareva djelovanja povjesničarka umjetnosti naziva fazom objektivacije te je smješta u veliko i u jugoslavenskom kontekstu burno i intenzivno društveno-političko razdoblje između 1920. i 1970. te naglašava kako je Mišin kritički aparat nepromijenjen unatoč društvenim promjenama od kapitalističkoga međuraća, fašizma do socijalističkoga modernizma, napominjući da se u socrealističkom razdoblju Miše ne bavi likovnom kritikom. I u (ranoj) fazi objektivacije, naglašava, Miše zadržava vitalističke temelje kritičkoga diskursa, odnosno neodvojivost umjetnosti od života, no usmjerenost pejzažizmu izraženu u slikanju dalmatinskih krajolika slikara postupno odvlači predmetu. Mogli bismo reći kako estetiku akta nadomješta estetika predmeta ili, kako to Šeparović vješto sabire: „,Objektivacija’ kao dominantno mimetički odnos prema objektu, predstavlja jedno od najvažnijih uporišta Mišine kritičke provjere ovoga razdoblja. Primarno je fokusiran na formu umjetničkog djela (boja, linija, oblik, kompozicija...), a za sadržajnu komponentu nema sluha ni kritičkoga aparata, pa ju u pravilu prešućuje" (42). U ovom se razdoblju očituje i Mišin razvijeni elitizam koji autorica povezuje sa slikarskim formalizmom, iz čega se može zaključiti kako između formalizma i elitizma stoji jednakost. Uz ovaj argumentima posve branjiv i dokazan izvod čini se kako autorica ne nastoji prikriti vlastitu, svakako suvremenu nesklonost naglašavanju formalnih aspekata umjetničkoga djela (i umjetnosti same kao redukcije na djelo) pa bismo morali istaknuti i kontekst ove vječne rasprave.

Naime, u prikazu Mišina favoriziranja formalizma autorica je vidjela elitizam, što je svakako utemeljeno u argumentaciji, a ona je u godinama Mišina stvaranja formulirana i među lijevim filozofima umjetnosti (Benjamin, Bloch, Marcuse i drugi) koji su Kantovoj apologetici „bezinteresnog” i „nesvrhovitog” formalističkog sviđanja suprotstavili nužnost tendencioznosti i svrhovitosti, riječju angažmana, jer, po njihovu shvaćanju, umjetnost nije u samom umjetničkom predmetu. Ipak je potrebno, čak i pod današnjim trendom „čitanja” umjesto „gledanja” slikarstva, postaviti pitanje je li doista sadržaj (tema) ono odlučno umjetničkoga djela, pa i opredjeljenje za određenu temu kriterij dobre ili loše umjetnosti (za Mišu je „forma apsolut, a sadržaj nevažan”, piše Šeparović). Neki će, naprotiv, tvrditi da ono bitno umjetnosti leži upravo u formi (također će lijevo orijentirani Adorno u Estetičkoj teoriji napisati da je „umjetniku forma sadržaj”), jer jedino ona dijeli umjetničko od ostalih djela koja se mogu baviti istim ili sličnim sadržajem. Tako će, primjerice, neka feministički usmjerena sociološka ili historiografska studija egzaktnije ustvrditi opresiju nad ženama tijekom nekoga razdoblja, no umjetničko će djelo upravo svojom formom imaginacije progovarati o istoj temi na način na koji to znanost neće moći, pa je obrana forme (ne i apsolutnoga formalizma) ujedno obrana umjetnosti same.

Iz istoga polazišta autorica naglašava slikarov esteticizam nasuprot tendencioznosti i angažmanu, pokazujući kako Miše „umjetničko djelo razumijeva kao lijep predmet koji je izdvojen iz društveno-političkog okruženja u kojem nastaje" (44). Ovime, po našem sudu, dolazimo do odlučne točke autoričina nastojanja, a nazvali bismo ga rušenjem mita o neutralnosti umjetničkoga stvaralaštva. Za Šeparović, sasvim je razvidno, umjetnost ni u najvišem stupnju formalizma i 
„estetske čistoće” ne može jamčiti neutralnost jer je uvjetovana subjektivnim i objektivnim kontekstom stvaralaštva. Autorica vjerno brani takvo polazište argumentirajući da Miše hijerarhizira umjetničko polje koje je za nj autonomno, izuzeto iz društvenih praksi, a umjetnik je neovisan o društveno-političkim procesima te odlučno argumentira kako „takav sustav vrijednosti kritičke provjere koji umjetnost tretira kao ideološki neutralnu sferu ljudskog stvaranja, nerijetko rezultira prikrivanjem stvarnih klasnih, rodnih, statusnih i raznih drugih društvenih antagonizama i asimetrija” (44).

Ova je autoričina teza fundirana ponovno u doticanju filozofskih utočišta, a smješta je u ničeansku dionizijsko-apolonijsku dihotomiju. Šeparović je tako demonstrirala kako fazu subjektivacije (dionizijsku) sada odmjenjuje faza objektivacije (apolonijska), a ako bismo vjerno slijedili Nietzschea, upravo je apolonijska umjetnost moć oblikovanja lika i slike. Vidi se to po autoričinu uvidu kako za osnovni preduvjet stvaranja Miše ističe posjedovanje talenta i iskustva te poznavanje zanata pa su to ujedno i kriteriji za prosudbu i isključenje drugih iz slikarskoga procesa, osobito amatera i mlađih slikara lišenih iskustva. Premda autorica u tome vidi elitizam, čini nam se kako se Mišin opis slikarske „,borbe” s predmetom, kako je autorica apostrofira, može razumjeti i kao posve uobičajen zahtjev za pravila majstorstva koje se i danas najprije odmjerava i provjerava umijećem što vjernijega oponašanja predmeta. I dok bismo se sasvim školnički mogli složiti kako je zahtjev da slika konja mora što vjernije preslikavati ili konja u prirodi ili prirodu konja sasvim legitiman, Šeparović otkriva nešto sasvim drugo i zasigurno upućenijoj likovnoj publici. Naime, riječ je o stilskom izrazu. Suvremena stremljenja te „slikanje napamet”, a to će reći odmicanje od predmetnosti, svjedoče, smatra Miše, intelektualiziranomu estetizmu koji dokida izravnost izraza te vodi u dekorativnost i maniru te, autorici vrlo važno, u sugestiju temata. Tako Šeparović dokazuje kako za Mišu u oba slučaja kao najveći problem (primjerice u Mujadžića, Gecana, Tabakovića, Šumanovića, Krizmana i ranoga Vidovića) izranja dominacija sadržaja nad formom, „što je unutar Mišine kritičke doktrine za svaku osudu: po njemu forma je apsolut, a sadržaj nevažan" (45). Povjesničarka umjetnosti zaključuje kako favorizirajući formu Miše ostaje slijep na sadržaj i izvanredno detektira kako djela imenuje samo po nazivu ili žanru (portret, pejzaž, mrtva priroda, figura), a umjetničkim izrazima koji se okreću sadržaju samo lijepi etiketu literarne (Vidović), ilustrativne (secesija) ili programatske (propagandne, agitatorske) umjetnosti (udruženja Medulić i Zemlja). Objektivacija, kako ju je autorica nazvala, dominantan je kriterij Mišine likovne kritike ovoga razdoblja. Njemu je realizam jedini prihvatljiv stilski model pa podržava uglavnom pripadnike svoje generacije koji zastupaju liniju njegova umjerenoga modernizma (Račić, Kraljević, Becić, Dobrović, Šulentić, Šeremet i drugi), a odbacuje sve one koji se odmiču od realizma, odnosno predmetnoga slikarstva, sklone avangardnim i apstraktnim stremljenjima (Herman, Tartaglia, Motika, Kožarić, Vaništa). Stoga je, zaključuje Šeparović, upravo „dogma ,objektivacije' uvjetovala privilegiranje formalnoga aspekta djela nad sadržajnim" (46).

Ovi doista važni autoričini uvidi o odnosu forme i sadržaja ukazuju nam i na neka epohalna proturječja između europske literature o umjetnosti i domaće likovne prakse ili kritike, koje je doista bitno spomenuti jer pružaju mogućnost komparativnoga pristupa omogućena ovom autoričinom analizom. Naime, u istom razdoblju kada Miše objavljuje svoje kritike (eseje) Ortega y Gasset u iznimnoj studiji Dehumanizacija umjetnosti iz 1925. pokazuje nešto sasvim oprečno, a bitno je za odnos forme i sadržaja umjetničkoga djela kojim autorica analizira Mišinu umjetničku misao. Prema razumijevanju španjolskoga filozofa umjetnosti, bijeg u apstrakciju donijele su mlade slikarske snage upravo kako bi prodirućim masama otrgnule razumijevanje umjetnosti kao poretka doslovnosti. Bijeg iz realizma i figurativnosti u apstraktni formalizam, smatrao je Ortega y Gasset, ne dopušta masama da u umjetnosti vide odraz vlastitih života i produžetak borbe za očuvanje stvarnih odnosa jer „prava” umjetnost ne polazi od stvarskoga, odnosno predmetnoga. Tako se Mišin elitizam koji bi se branio realizmom, autorica nam otkriva, 
sasvim izravno sudara s europskim misaonim trendovima prema kojima elitizam osvjedočen otporom prema prosječnosti masa postupno dolazi s avangardom, odnosno apstraktnim slikarstvom, a ne s obranom već umornoga realizma.

Osobitu usmjerenost Šeparović polaže u prikaz Mišina elitizma kao antifeminizma, čime studija i završava. Dok je u ranoj fazi slikar elitizmu svjedočio u kontekstu nacionalnoga kompleksa, teoriji genija te naglašenoj individualnosti i subjektivnosti, kao afirmirani zagrebački slikar, srednjoškolski nastavnik, a poslije i profesor na ALU-u i član JAZU-a, Miše pokazuje vrhunac elitizma. Uz napuštanje demokratizacijskih stavova (decentralizacija likovno-izlagačke prakse, likovno obogaćivanje provincije), Miše se, argumentira autorica, otvoreno deklarira kao antifeminist u trenucima združenoga stupanja žena na likovnu scenu prvom izložbom Kluba likovnih umjetnica 1928. Šeparović ne ostaje na ovome za to vrijeme sasvim uobičajenome difamirajućem odnosu prema ženama, već ide korak dalje, nastojeći pokazati kako antifeminizam naših etabliranih slikara nije odraz nekog općeg patrijarhalnog duha vremena, nego je motiviran bojazni od gubitka muških privilegija na području likovne umjetnosti. Time autorica u odnos uvodi rodno-klasnu komponentu jer Miše, kao i Babić, ovakvim „ispadom zapravo vode borbu za održavanje sustava rodno-spolne dominacije” (52). Šeparović ide još i dalje zaključujući da su kritiku „ženske” umjetnosti uputili uvaženi umjetnici i profesori (budući akademici) iz razloga koji nije samo antifeministički nego i ekonomsko-interesni, osvjedočen time da je zapravo riječ o eliminaciji konkurencije koju vide u slikaricama. Unatoč tomu što bi se netko mogao upitati zašto bi bardovi jugoslavenskoga slikarstva strahovali upravo od neetabliranih slikarica (žena) jednako ili više nego od ostalih etabliranih slikara (muškaraca), moramo se složiti da nam je autorica pružila dobru argumentaciju koja raskrinkava ono što smo znali, ali nismo imali hrabrosti misliti. Pa ipak, da bi argumentacija, upravo radi osnaženja pristupa i dodatne provjere teze, bila još istaknutija (a autorica ju je već dovoljno učvrstila prikazom Mišine kritike slikarstva Naste Rojc), bilo bi dobro, možda u nekoj budućoj studiji, usporediti snagu njegova kriticizma prema drugim slikarima, onako kako je to najizravnije učinjeno prema „zemljašima”, te vidjeti jesu li blaže ili još izraženije u odnosu na kritiku rada slikarica kako bi se izbjegla mogućnost da u novijim, osobito feminističkim čitanjima usmjerenima na detektiranje muške žudnje za rodno-spolnom dominacijom ne dođe do zamjene jednoga esencijalizma drugim jer je slobodarska snaga feminizma (osobito egzistencijalističkoga de Beauvoir) počivala upravo na odbacivanju svakoga esencijalizma (reduciranja na bit ili tipičnost).

Zaključili bismo kako je Šeparović izradila iznimnu studiju koja probija nove horizonte i raskrinkava nešto što nismo imali snage dovesti do svijesti. Riječ je o novom, drukčijem, hrabrijem i složenijem pristupu analizi umjetnosti koja ne staje na formalističkim zakonitostima struke, već se pronalazi u širini argumenata fundiranih u filozofskim, političkim i društvenim kontekstima koji šire vidike i podižu svijest na višu razinu. Knjiga je pod uredničkom rukom Libuše Jirsak sa svim instruktivnim pojašnjenjima i prilozima te studijom Ane Šeparović, čija je analiza donijela svjež i provokativan pristup, postala nezaobilazan ugaoni kamen pristupa ne samo Jerolimu Miši nego i bogatomu razdoblju jugoslavenske i hrvatske kulture 20. stoljeća, ali i putokaz mlađim generacijama ukazujući im da na slikarstvo mogu gledati nekim drugim očima. 